\title{
A Atividade Legislativa e a Tese de Repercussão Geral para a Proteção do Domicílio Privado
}

\author{
José Wilson Ferreira Lima*
}

\begin{abstract}
1 Introdução. 2 Aspectos gerais do crime de abuso de autoridade. 3 Redefinição do crime de abuso de autoridade. 4 Jurisprudência do Supremo Tribunal Federal sobre o abuso de autoridade. 5 Direitos fundamentais: entre a essencialidade e o pragmatismo. 6 Interpretação e retórica no julgamento do Recurso Extraordinário n. 603.616-RO. 7 Conclusão. Referências.
\end{abstract}

\section{RESUMO}

O artigo desenvolve análise crítica em torno da sistematização sobre a adequada interpretação do crime de abuso de autoridade decorrente da violação de domicílio, do qual resulte prisão de pessoas e/ou apreensão de bens e objetos relacionados, em tese, com a prática de infrações penais. A abordagem coloca no centro da discussão a análise de conteúdo retórico de normas jurídicas criadas com a pretensão de garantir a satisfação plena de direitos fundamentais individuais em confronto com a política de combate à criminalidade, destacando-se o conflito de adequação e finalidade entre o PLS n. 85/2017 (Senado), o RE n. 603.616-RO (STF) e a Constituição Federal (CF). O estudo é oportuno e relevante, tendo em vista que contextualiza o atual cenário de indefinições que envolve toda a máquina política e administrativa do Estado brasileiro, quanto à tomada de decisões legislativas no âmbito da política criminal, e o descompasso entre a pretensão garantista dos direitos fundamentais, o controle da atividade policial e a nova definição do crime de abuso de autoridade, colocados como desafios da política legislativa penal.

Palavras-chave: Direitos Fundamentais. Interpretação Jurídica. Tese de Repercussão Geral. Proteção do Domicílio Privado.

\section{INTRODUÇÃO}

A interpretação da norma jurídica sempre foi situação desafiadora para todos que se envolveram - e ainda se envolvem - com a tarefa de conhecer e determinar o sentido mais aproximado das palavras que compõem o enunciado da norma, buscando vencer, quase sempre, os limites da literalidade estrita e integrar seus sentidos a partir de acontecimentos e padrões interpretativos próprios de uma época (fator histórico) e de um lugar, segundo os critérios valorativos típicos da localidade e de sua cultura (fatores sociais), lembrando-se de que, na

Doutorando em Direito - Centro Universitário de Brasília. Mestre em Direito Constitucional - Instituto Brasiliense de Direito Público. Promotor de Justiça - Ministério Público do Distrito Federal e Territórios. E-mail: <wferreiraster@gmail.com>. http://orcid.org/0000-0002-9996-3485 
“interpretação, sempre está pressuposto algo diretamente dado: um texto” (SAVIGNY, 2001, p. 8). Nesse aspecto, talvez o maior desafio a ser enfrentado no âmbito da política legislativa seja o de produzir leis, claras e objetivas, que favoreçam a satisfação concomitante dos direitos fundamentais individuais e a máxima concretização da segurança pública, assegurando-se, ademais, de que as normas fundamentais, como "grandeza formal", constituam a unidade na multiplicidade das normas (MÜLLER, 2017, p. 302). A interpretação assume relevância imensurável diante do fenômeno jurídico-social, especialmente devido aos conflitos gerados diante das diferentes racionalidades presentes na formulação e na execução da política, tendo em vista a dualidade dos ambientes que a incorporam: o político e o técnico. Observa-se, com isso, que, em algumas situações, "falta o substrato técnico e as decisões são tomadas sem base suficiente para que possam alcançar resultados eficazes e efetivos. Em outras, tende-se a supervalorizar o papel dos políticos." (MACHADO; ALVES, 2017, p. 57).

O objetivo deste estudo é desenvolver análise crítica em torno de possível sistematização sobre a interpretação mais adequada do crime de abuso de autoridade decorrente da violação de domicílio, do qual resulte a prisão de pessoas e/ou apreensão de bens e objetos supostamente relacionados com a prática de infrações penais, que possam concorrer em prejuízo dos direitos fundamentais dos indivíduos envolvidos na persecução, com gravames, diretos ou indiretos, a direitos, como à liberdade e à inviolabilidade do domicílio. Essa abordagem coloca no centro da discussão a análise de conteúdo retórico de normas jurídicas criadas com a pretensão de garantir a satisfação plena de direitos fundamentais individuais, valendo-se, para tanto, de mecanismos interpretativos que, não raras vezes, ofuscam e até tornam inefetivas essas garantias. Com esse propósito, merece destaque o Projeto de Lei do Senado (PLS) n. 85/2017 que, se convertido em lei, redefinirá o crime de abuso de autoridade (nova tipologia) praticado com violação ao domicílio alheio (BRASIL, 2017a). Pretende-se demonstrar, com o exame do destacado projeto, como a interpretação da futura norma penal incriminadora poderá ter sua compreensão distorcida quando houver interesse em se produzir argumentos que deem suporte a um juízo seguro de culpa, do qual decorrerá a reprovação penal, ou quando esse interesse tiver conteúdo oposto. Nesse contexto, é importante ter em vista que as "palavras e os enunciados constitucionais podem dar margem a diversas significações e a sentidos diametralmente opostos, a depender das circunstâncias fáticas e dos interesses envolvidos." (ALVES JUNIOR, 2010, p. 133).

Metodologicamente, o estudo se apoiará na exploração teórico-argumentativa especialmente calcada na definição que se pretende atribuir ao crime de abuso de autoridade constante do indicado projeto de lei, que representa a tomada de nova decisão legislativa no âmbito da persecução criminal, assim como nas razões que fundamentaram a tese de repercussão geral adotada no Recurso Extraordinário (RE) n. 603.616-RO, que teve curso e julgamento no Supremo Tribunal Federal (STF), tudo isso contando com o refinamento da doutrina desenvolvida em torno dessa temática. 
O estudo é oportuno e relevante, tendo em vista que contextualiza o atual cenário de indefinições que envolve o aparelho político e administrativo do Estado brasileiro, o descompasso entre a pretensão garantista de proteção dos direitos fundamentais e o controle da criminalidade, perspectivado segundo o viés da segurança pública. Para se ter critério objetivo, adota-se como pressuposto de estudo a impessoalidade, isso porque não há qualquer pretensão de abordar ou examinar fatos concretos associados a indivíduos em particular, mas tão somente desenvolver análise valorativa de argumentos quanto à interpretação da norma penal selecionada. É nesse contexto que se instala a problematização do estudo, que consistirá em determinar se há e quais seriam os limites, claros e definidos, para que os agentes públicos integrantes dos órgãos de segurança pública (como policiais federais, civis, militares etc.) decidam quando ingressar no domicílio alheio, à revelia da existência de prévia autorização judicial, diante de suposta situação de flagrante delito, que justificaria a tomada de tal decisão, considerando que tal situação deveria ser racionalmente resolvida nas decisões legislativas (leis), atendendo aos seus respectivos critérios valorativos. Nesse contexto, a política legislativa, como canal de normatização de políticas públicas, deve procurar materializar a convergência entre o funcionamento dos órgãos estatais e a formação de seus atores (SUXBERGER; CANÇADO, 2017).

Em torno do objeto de estudo, o Estado brasileiro assumiu nova proposta de "política criminal de crise", essencialmente voltada para o campo do direito punitivo e, por tal razão, novos esforços argumentativos e interpretativos são necessários para a correta e adequada compreensão do direito à inviolabilidade do domicílio, de modo a se preservarem os direitos fundamentais inerentes à pessoa humana. Nesse aspecto, compete ao intérprete o dever de analisar a norma, buscando conhecer seu conteúdo e sentido, sabendo-se que a interpretação é a reconstrução do conteúdo da lei (SAVIGNY, 2001, p. 9), sem se descuidar de sopesar e considerar que "a política criminal, que se importa com os conteúdos sociais e fins do Direito Penal, encontra-se fora do âmbito do jurídico." (ROXIN, 2002, p. 12). Ademais, ao se tratar de crise no contexto da política criminal, deve-se buscar o atendimento mais aproximado das garantias constitucionais e das que emanam do sistema internacional de proteção dos Direitos Humanos, de modo que a constatação mais preocupante nesse debate está relacionada com a forma débil ou nula da manifestação das garantias constitucionais mais sensíveis em favor do indivíduo (RUSCONI, 2005). Essa reflexão é atual e também essencial na discussão quanto à aplicação e à incidência dos direitos fundamentais, na medida em que, se estes não forem adequados e suficientemente protegidos, ter-se-á por prejudicado todo o projeto constitucional brasileiro, que se assenta na premissa de formar uma sociedade justa, solidária e regida pelo Estado de Direito.

\section{ASPECTOS GERAIS DO CRIME DE ABUSO DE AUTORIDADE}

A Lei n. 4.898/1965, que dispõe sobre o crime de abuso de autoridade, tipifica como infração penal a conduta que atenta contra a inviolabilidade do domicílio (art. 3o, "b"), sancionando-a com multa, pena privativa de liberdade, perda do cargo e inabilitação para 
o exercício de qualquer função pública, sem prejuízo da aplicação de sanções civis e administrativas (BRASIL, 1965). Para o fim de caracterizar o crime em comento, considera-se autoridade toda pessoa que exerça cargo, emprego ou função pública, de natureza civil ou militar, em caráter efetivo ou transitório, e independentemente de remuneração $\left(\operatorname{art} .5^{\circ}\right.$ da Lei n. 4.898/1965). Nesse aspecto, a menção a agentes públicos é abrangente para todos os servidores, mas, por questão de especificidade, atinge diretamente os servidores públicos policiais, de qualquer espécie, tendo em vista a condição de serem eles os responsáveis pela realização da persecução criminal. Para contextualizar o crime em exame, do ponto de vista de sua gravidade, basta considerar que a sanção máxima a ele cominada é de 6 (seis) meses de detenção, o que o classifica como infração de menor potencial ofensivo, em conformidade com o que dispõe o art. 61 da Lei n. 9.099/1995 (BRASIL, 1995). Por essa razão, e ante ao reconhecimento de que se trata de crime de ação pública, o agente público, considerado autoridade conforme definido em lei, que incorrer na descrita infração poderá se beneficiar com a aplicação imediata de pena restritiva de direitos ou multa, isto é, poderá se beneficiar com o instituto da Transação Penal (art. 76). Sabidamente, "para qualquer área do conhecimento humano, transação é negociação, é o ajustamento de determinados efeitos ou resultados, implicando renúncia a direitos e aceitação de certas obrigações.” (ZANATTA, 2001, p. 44). Assim, de acordo com a realidade jurídica brasileira, a consequência imediata da transação penal é que ela impede a instauração da ação penal, afastando, com isso, a aplicação da pena privativa de liberdade (finalidade despenalizadora).

Cumpre observar, não obstante, de acordo com a ordem constitucional vigente, que se considera casa o asilo inviolável do indivíduo e, por essa razão, ninguém pode penetrar e/ou nela permanecer, senão com o consentimento do morador, exceto nas hipóteses de: i) flagrante delito, ii) desastre, iii) para prestar socorro, ou, ainda, iv) durante o dia, em cumprimento à determinação judicial (BRASIL, 2016). Percebe-se, então, que, nesse ponto, a Constituição Federal (CF) de 1988 dispôs taxativamente sobre as possibilidades que representam formas autorizadas de violação da intangibilidade do domicílio alheio. Trata-se, portanto, de expressão normativa de envergadura constitucional, que define o direito (à inviolabilidade do domicílio $\mathrm{CF}$, art. 5\% XI), ao mesmo tempo em que explicita situações concretas diante das quais é possível haver a violação, sem que isso constitua infração penal (BRASIL, 2016). Consequentemente, isso implica uma forma de flexibilização desse direito fundamental, algo correspondente à sua relativização e que, por isso, enseja interpretação restritiva. Nesse contexto, o binômio direito/ garantia de que trata o art. $5^{\circ}, \mathrm{XI}$, da CF guarda correspondência literal com a norma penal incriminadora já mencionada, disposta no art. 3o, b, da Lei n. 4.898/1965. Todavia, deve-se questionar se entre a norma constitucional e a norma penal destacada existe correspondência sistemática e finalística, numa relação de adequação e de proporcionalidade, admitindo-se que a infração a um direito processual constitucional vincula-se necessariamente ao direito individual de não sofrer, por exemplo, busca e apreensão indevidas, o direito a não produzir provas contra si, o de ser assistido por advogado, o devido processo legal, etc. (DEU, 2014). 
Atente-se que a dimensão normativa do crime de abuso de autoridade deveria cumprir a dupla função de resguardar o correspondente direito fundamental atribuído ao indivíduo e estabelecer limites contra a ingerência abusiva da ação estatal, que concorra contra os direitos e as garantias individuais afirmados na CF, respeitando-se a ordem constitucional democrática (ROXIN, 2002). Em acréscimo, não se pode olvidar que a ordem jurídica como um todo, em seu conteúdo constitucional e infraconstitucional, contribuiu para a formação desses direitos, ditos de intervenção, com os quais se torna possível harmonizar a liberdade individual com as necessidades sociais. À luz dessa realidade, cita-se, a exemplo da prática jurisprudencial norte-americana, a "Regra da Exclusão" (Exclusionary Rule), que busca prioritariamente impor limites à procura de elementos incriminatórios, preservando determinados direitos constitucionais contemplados em diferentes Emendas da Constituição dos Estados Unidos (DEU, 2014). No Brasil, o regramento legal quanto às provas ilícitas ou proibidas teve como referencial o experimentalismo processual praticado nos Estados Unidos, de modo que aqui foi fixado o princípio geral da inadmissibilidade das provas obtidas ilicitamente, que tem como consequência a vedação de seu emprego no processo (AMBOS, 2009). Nessa ordem, compreende-se por "provas ilícitas" as que forem produzidas com violação às garantias constitucionais ou conflitarem com as leis de direito material, ao passo que "provas ilegítimas" são as produzidas em desacordo com as leis processuais (AMBOS, 2009).

\section{REDEFINIC̣ÃO DO CRIME DE ABUSO DE AUTORIDADE}

Na atualidade, momento em que a Lei n. 4.898/1965 (BRASIL, 1965) conta com mais de meio século de existência e vigência, foi apresentado no Parlamento brasileiro o PLS n. 85/2017 (BRASIL, 2017a), que dispõe sobre o novo regime do crime de abuso de autoridade, o qual se aperfeiçoará mediante a violação do domicílio alheio, com condutas consistentes em invadir ou adentrar, clandestina, astuciosamente e à revelia da vontade do ocupante, o imóvel alheio ou apenas em uma ou algumas de suas dependências, bem como nele permanecer, nas mesmas condições, sem prévia autorização judicial e sem observar os regramentos legalmente estabelecidos. Além dessas condutas, também caracterizarão abuso de autoridade: i) coagir alguém, mediante violência ou grave ameaça, a franquear-lhe o acesso ao imóvel ou às suas dependências, ii) executar mandado de busca e apreensão em imóvel alheio ou em suas dependências, mobilizando veículos, pessoal ou armamento de forma ostensiva e desproporcional, ou de qualquer modo extrapolando os limites da autorização judicial, de modo a expor o investigado à situação vexatória e iii) cumprir busca domiciliar após as 21 horas e antes das 5 horas (BRASIL, 2017a).

Em conformidade com as inovações legislativas propostas, o projeto de lei introduzirá duas variáveis. A primeira, quando a infração for praticada mediante violação de domicílio, será aplicada pena privativa de liberdade, de 1(um) a 4(quatro) anos de detenção, e multa, o que permitirá que o agente responsável pela conduta incriminada (violação de domicí- 
lio) se beneficie com a suspensão condicional do processo, de que cuida o art. 89, caput, da Lei n. 9.099/1995 (BRASIL, 1995). A segunda assegura que não haverá crime quando para o ingresso no domicílio houver "fundados indícios", que indiquem a necessidade de tal medida em razão de situação de flagrante delito ou de desastre (art. 22, § 2०, PLS n. 85/2017) (BRASIL, 2017a). Entretanto, convém observar que a suspensão condicional do processo tem incidência direta sobre o curso da ação penal, uma vez que ela susta o seu prosseguimento logo após o recebimento da peça acusatória (denúncia), conquanto o réu preencha determinados requisitos, aceite e cumpra certas condições durante prazo certo (de 2 a 4 anos), findo o qual restará extinta a punibilidade, desde que o beneficiário não tenha dado causa à revogação do benefício. Trata-se, portanto, de espécie de transação processual, autorizada pela Constituição (art. 98, I, CF) e fundada no denominado "espaço de consenso" (MIRABETE, 1998, p. 151). Mas, em princípio, não parece meritório abrir-se discussão mais intensa sobre as hipóteses de violação de domicílio, quando se tem o objetivo de prestação de socorro ou mesmo para atender à ocorrência de desastre. Todavia, a mesma tranquilidade não se terá se o ingresso de agentes públicos no imóvel alheio tiver como pressuposto o flagrante delito, caso em que, concorrentemente, vários direitos individuais fundamentais podem ser violados, como a própria invulnerabilidade do domicílio, a liberdade, a privacidade e a intimidade das pessoas que se encontrarem presentes, sejam elas residentes ou não no local da diligência. Desse modo, se o novo projeto excepciona formas de caracterização do crime, tal como definido pela CF de 1988, essa discussão poderia parecer desnecessária. Mas, a se exigir que o ingresso no imóvel alheio, nos casos de flagrante delito, seja circunstanciado, isto é, que haja "fundados indícios" que justifiquem e autorizem a concretização dessa medida, quando não se tem prévia ordem judicial, poderão surgir algumas complexidades, as quais darão margem para vasto campo de possibilidades interpretativas, que não podem ser ignoradas ante a imensurável capacidade humana de fazer ajustes de oportunidades, atendendo-se às necessidades ocasionais que a situação concretamente exigir e às conveniências individuais estratégicas.

Percebe-se, enfim, que, tanto na atual definição do crime de abuso de autoridade, como na contida no PLS n. 85/2017 (BRASIL, 2017a), o legislador criou, estrategicamente, mecanismos despenalizadores, isto é, abriu a possibilidade para que os agentes públicos, a quem se atribua a violação criminosa do domicílio alheio, possam se beneficiar com medidas diversas da privação de liberdade, pois, como visto, pela atual definição desse crime, o infrator, em geral servidor público integrante dos órgãos de segurança pública, poderá se beneficiar com a transação penal, ao passo que, em relação ao novo crime proposto, poderá se beneficiar com a suspensão condicional do processo. Nesse contexto, e em conformidade com a orientação doutrinária, entende-se por despenalização o ato ou a medida de diminuir a pena atribuída a uma infração penal sem descriminalizá-la, isto é, sem retirar de sua essência o caráter de ilícito penal. Desse modo, são exemplos de medidas despenalizadoras: a prisão de fim de semana, a prestação de serviços de utilidade pública, a multa reparatória, a indenização à vítima, a prisão 
domiciliar, a inabilitação, a diminuição do salário e todas as medidas de cunho reeducativo previstas nos sistemas penais-punitivos. Com efeito, a adoção de medidas despenalizadoras justifica-se a partir do reconhecimento de que, às vezes, é "conveniente manter a ilicitude do fato, eliminando-se somente a pena, evitando um possível excesso da conduta nessas áreas e ratificando a suposta tarefa de docência moral da legislação.” (CERVINI, 2002, p. 85). Nessa medida, além de não se ter, com clareza e objetividade, parâmetros com os quais se possa interpretar a expressão "fundados indícios", como elemento justificante da decisão de ingresso no imóvel alheio, perde-se a noção da gravidade e do valor que representa o bem jurídico "domicílio" protegido pela norma constitucional, se o agente público responsável pela violação somente tiver que se submeter a medidas despenalizadoras, como a suspensão condicional do processo (situação proposta no projeto) ou a transação penal (situação atual), o que torna evidente a ausência de proporcionalidade entre a construção de normas protetivas de direitos fundamentais e a medida de sancionamento imposta aos agentes públicos causadores de violações a direitos dessa natureza.

Mas, o que parece sintomático e não evidencia explicação lógica minimamente aceitável é que, ao mesmo tempo em que se alcançou pela via da positivação constitucional o estabelecimento de normas protetivas de direitos fundamentais, como expressão máxima do Estado de Direito, que deveriam atuar como mecanismos garantidores da intangibilidade do domicílio privado, tem-se, paradoxalmente, a criminalização de conduta reconhecida como violadora de tal garantia, mas associada a um padrão sancionatório desproporcional e incompatível com a grandeza e o status do correspondente direito fundamental. Ou seja, é como se ao mesmo tempo em que se afirma a grandeza do bem jurídico "domicílio" e a sua importância para a satisfação da dignidade humana, não se tenha justa motivação para sancionar o transgressor desse bem jurídico com reprimenda que esteja à altura. Nessa ordem, importa considerar que a "dignidade deve ser desenvolvida como conceito e como prática, numa visão política abrangente." (VARELLA; SANTOS, 2016, p. 185). A propósito, vale lembrar que o "positivismo, considerado como teoria jurídica, caracteriza-se especialmente por levar para fora do direito as dimensões sociais e políticas." (ROXIN, 2002, p. 12). Essa leitura se torna evidente e compreensível na medida em que o legislador responde ao crime de abuso de autoridade com a possibilidade de aplicação da transação penal e, ainda, prepara nova lei para dispor sobre esse mesmo crime, mas cuja resposta penal não será substancialmente mais intensa, ante a possibilidade de o agente público violador do domicílio alheio responder por essa infração com o instituto despenalizador da suspensão condicional do processo. Aliada a essa paradoxal política criminal em gestação, que criminaliza, mas simultaneamente despenaliza, o novo projeto de lei introduzirá no ordenamento jurídico, de forma taxativa e expressa, o argumento segundo o qual caberá ao próprio agente violador do domicílio alheio a decisão sobre a existência de "fundados indícios" com os quais poderá ingressar no imóvel particular, prender pessoas e apreender bens, objetos etc. Nesse sentido, o projeto de lei expressamente dispõe em seu art. 22, $\$ 2$, que "não haverá crime se o ingresso for para prestar socorro, 
ou quando houver fundados indícios que indiquem a necessidade do ingresso em razão de situação de flagrante delito ou de desastre." (BRASIL, 2017a, online).

Trata-se, indiscutivelmente, de cláusula aberta, que confere amplo poder de decisão franqueado ao agente público, que poderá construir posteriormente, livre e sem nenhuma forma de controle, os "fundados indícios" que justificarão sua decisão. Por conseguinte, é de todo interesse delimitar o significado legal e prático de "indícios" no contexto da teoria da prova. Nessa seara, é oportuno ter claro que a prova indiciária tem fundamento em presunções e indícios, palavras que, na origem, isto é, etimologicamente, guardam entre si o mesmo significado, podendo-se afirmar, para efeitos de prova no processo penal, que apresentam qualidade jurídica aparentemente idêntica. Contudo, "indício", palavra de raiz latina, corresponde a "apontar" ou "indicar" e tem "valor sugestivo", isso porque a prova é sugerida por um conjunto de circunstâncias que criam uma conjectura de probabilidade, o que, verdadeiramente, não é prova e não leva ao grau de certeza que se espera no processo penal. Nesse sentido e de acordo, primeiramente, com o art. 239 do CPP, "indício" é a "circunstância conhecida e provada, que, tendo relação com o fato, autorize, por indução, concluir-se a existência de outra ou outras circunstâncias." (BRASIL, 1941, online). Mas, quanto a isso, é preciso cautela, sabendo-se que, embora os indícios sejam de grande utilidade como guias na investigação para a busca de provas, impõe-se atenção especialmente contra as insídias dessa espécie probatória, que deve estar devidamente em consonância com o contexto probatório e ainda considerar, escrupulosa e ponderadamente, as razões determinantes da ação investigativa (MALATESTA, 2001). Ademais, o peso da causa penal, bem como o significado e o valor probatório dos mais extensos meios de provas, devem entrar em ponderação com os prejuízos para a justiça do caso, da dilação e da complexidade do processo (DIAS, 2011).

É de rigor que indícios devem ser provados, não se admitindo, em regra, sejam provados por outros indícios, razão pela qual não se qualificam como prova, mas como elementos indicativos, sendo considerados contingentes e inaptos para dar certeza daquilo que objetivam provar (MALATESTA, 2001), lembrando-se, ademais, de que a "prova indiciária é a mais perigosa de todas as provas.” (MESSIAS, 2001, p. 466). Diante de tais considerações, a conclusão mais sensata é a de que o indício não representa prova cabal e definitiva de um fato, senão uma hipótese provável daquilo que se pretende provar.

Devido a isso, os "fundados indícios" de que trata o PLS n. 85/2017 (art. 22, § 20) devem ser interpretados junto à disciplina sobre os indícios tratada no CPP (art. 239), visto que deverão ser oportunamente provados, não se admitindo argumentos fundados em mera intuição ou "achismos", por parte do agente público no momento em que decida ingressar no imóvel alheio, onde supostamente esteja ocorrendo crime em situação flagrancial. Entretanto, há um segundo plano de considerações e de perplexidades que exige reflexões, pois se o mencionado PLS n. 85/2017 e o CPP fazem referências expressas aos "fundados indícios", o mesmo Código, em seu art. 240, $\$ 1^{\circ}$, condiciona que a busca domiciliar seja realizada quando "fundadas razões" a autorizem. Ou seja, diante desse outro dispositivo, caberia questionar se 
"fundados indícios" e "fundadas razões" são expressões equivalentes e, se não forem, como se poderá desenvolver uma linha interpretativa para o fim da aplicação racional do direito procedimental voltado para a regulamentação quanto ao ingresso de agentes públicos no domicílio privado, que possa ser mais adequada e próxima do comando constitucional, que busca preservar a inviolabilidade do domicílio.

\section{JURISPRUDENNCIA DO SUPREMO TRIBUNAL FEDERAL SOBRE O ABUSO DE AUTORIDADE}

Neste tópico, sem operar mudança de rumo, pretende-se fazer breve incursão nos principais aspectos dos debates desenvolvidos no julgamento do RE n. 603.616-RO pelo STF, tendo como principal foco o emprego sistematizado de "fundadas razões" como vetor de orientação para que o agente público - servidor policial, em geral - decida sobre o ingresso no domicílio privado, ante a suposta ocorrência de flagrante delito no interior ou em uma ou algumas dependências do imóvel (BRASIL, 2015b). Antes, porém, convém destacar que o STF havia decidido que "a garantia individual da inviolabilidade domiciliar cede à verificação do interesse público na persecução penal, daí a previsão constitucional acerca da possibilidade de o domicílio ser invadido." (BRASIL, 2008, p. 248).

No exame do referido RE, a proposta de discussão girou em torno de algumas garantias constitucionais presentes na CF (art. 5), entre as quais a legalidade das provas obtidas mediante invasão de domicílio por autoridades policiais, sem a posse de mandado de busca e apreensão. Para o STF, embora o texto constitucional disponha expressamente sobre a inviolabilidade domiciliar e suas possíveis exceções, a interpretação até então adotada havia se firmado no sentido de que, se dentro da casa estivesse ocorrendo crime permanente, seria possível o ingresso forçado pela polícia, independentemente de autorização judicial, reconhecendo-se que, por definição, nos crimes permanentes, há um interregno entre a sua consumação e o exaurimento. Desse modo, se dentro da residência ou de outro local protegido um crime permanente estiver ocorrendo, haverá situação de flagrante delito. Consequentemente, uma vez caracterizada essa situação, torna-se viável o ingresso forçado no domicílio. Nesse sentido, a orientação jurisprudencial do STF reconhecia que a situação flagrancial inerente ao crime permanente afastaria a inviolabilidade versada no inc. XI do art. $5^{\circ}$ da Constituição, tornando lícita a busca domiciliar (BRASIL, 2015c). Contudo, passou-se a entender que essa medida, sem justificativa conforme o Direito, poderá ser arbitrária, uma vez que não é a constatação da situação flagrancial posterior ao ingresso que justifica a medida, o que aponta para o necessário fortalecimento do controle a posteriori, exigindo-se dos policiais a demonstração de que a medida somente possa ser adotada diante de "justa causa”, isto é, se houver elementos aptos para caracterizar a suspeita de situação a autorizar o ingresso forçado no domicílio privado. Consequentemente, o modelo probatório deverá ser o mesmo previsto para o da busca e da apreensão domiciliar, que exige a demonstração de 
"fundadas razões", conforme previsto no art. 240, § 1, do CPP (BRASIL, 2015a, p. 14-15).

De plano, como se pode observar, "fundadas razões" é a terminologia empregada pelo CPP (art. 240, § 10) e é, portanto, importante elemento de interpretação a ser considerado, junto a "fundados indícios", terminologia empregada na composição do correspondente enunciado normativo de que trata o PLS n. 85/2017 (art. 22, § 20). Dessa forma, uma vez que o arranjo literal é o primeiro referencial interpretativo para se conhecer o sentido e o alcance da norma (interpretação gramatical), não se pode ignorar que, ao interpretar essas expressões, o intérprete poderá percorrer o mesmo caminho ou caminho diverso, desde que esteja suficientemente preparado para aceitar os possíveis resultados de sua investida, lembrando-se que, enquanto "fundadas razões" é a expressão empregada no vigente CPP e da qual o STF se utilizou em toda a extensão do RE examinado, "fundados indícios" é a expressão adotada pelo legislador para consubstanciar o novo tipo do crime de abuso de autoridade, cuja finalidade é, ao menos em tese, criar espaço de proteção para o domicílio privado contra as investidas criminosas de agentes vinculados ao Poder Público, como categoria de direito objetivo de envergadura constitucional. Diante disso, convém salientar que, no julgamento do destacado RE, o STF estabeleceu a tese de repercussão geral:

A entrada forçada em domicílio sem mandado judicial só é lícita, mesmo em período noturno, quando amparada em "fundadas razões", devidamente justificadas a posteriori, que indiquem que, dentro da casa, ocorre situação de flagrante delito, sob pena de responsabilidade disciplinar, civil e penal do agente ou da autoridade, e de nulidade dos atos praticados (BRASIL, 2015b, p. 62).

Percebe-se que o STF disciplinou a forma como deverá ser realizada a busca domiciliar, além de ter clarificado as responsabilidades do infrator que, antes de ingressar no imóvel, deverá ter sua decisão respaldada em: i) "fundadas razões”, as quais ii) deverão ser devidamente justificadas, posteriormente. Assim colocadas essas premissas, com as quais se busca conferir legalidade ao ato empreendido por agentes integrantes das forças públicas, que violarem o domicílio privado sem contar com a "prévia" e "necessária” autorização judicial, impõe-se breve e cuidadosa análise de alguns importantes argumentos expendidos no destacado RE. Como ponto de partida, tem-se que o RE foi manejado com a pretensão de se reconhecer a ilicitude das provas que foram obtidas por servidores policiais, mediante a invasão do domicílio privado, sem que dispusessem de prévio mandado de busca e apreensão. A propósito disso, admitiu-se que abusos podem ocorrer diante da tomada da decisão no sentido de forçar o ingresso na residência alheia, destacando-se que, em regra, são as comunidades em situação de vulnerabilidade social as que estão mais suscetíveis de serem vítimas de formas de ingerências arbitrárias em seus domicílios (BRASIL, 2015b).

Destacou-se, ainda, que o STF havia firmado sua jurisprudência sem nenhuma reserva, uma vez que admitia que servidores policiais poderiam ingressar no domicílio sem dispor de autorização do morador, na hipótese de flagrante por crime permanente e que, se mantida essa tese, ter-se-ia esvaziado o conteúdo da inviolabilidade do domicílio, o que ofenderia, portanto, a Constituição e os demais Tratados de Direitos Humanos dos quais o Brasil é 
signatário (BRASIL, 2015b). Seguindo nessa linha, reconheceu-se que abusos podem ocorrer tanto no momento de se tomar essa decisão, isto é, a de forçar a entrada no domicílio, como no momento de executar a medida de busca (BRASIL, 2015b). Enfatizou-se que, mesmo a despeito de sua importância, a busca domiciliar exige controle, pois sem isso um policial pode livremente ingressar na residência, realizar buscas e prisões, sem que tenha recebido a prévia e expressa autorização judicial, o que, embora seja um arranjo tradicional no direito nacional, é insatisfatório (BRASIL, 2015b). Nesse ponto, surge o dilema: nessa condição, se o policial decide ingressar no domicílio e obtém êxito em efetuar a prisão de alguém em razão da prática de crime permanente, certamente não será responsabilizado, mesmo diante da circunstância de não ter certeza quanto à ocorrência de flagrante delito, pois evidentemente poderá alegar o estrito cumprimento do dever legal, como tese defensiva. Todavia, com esse modo de agir e de justificar, a garantia da inviolabilidade do domicílio deixaria de existir concretamente, não passando de simples texto desprovido de força e de realização, reconhecendo-se, enfim, que é nessa situação que se encontra o País atualmente (BRASIL, 2015b).

Devido a isso, ao examinar o RE n. 603.616-RO, entendeu-se relevante tornar imperativa uma interpretação evolutiva que não apenas afirme a garantia constitucional da inviolabilidade da casa, mas que também confira amparo aos servidores policiais, oferecendo-lhes segurança e orientação quanto às suas formas de atuação (BRASIL, 2015b). Sobre a interpretação evolutiva, impõe-se ponderar que ela é mera aplicação do direito, repousando nos cânones da ratio legis, que é objetiva, e da ratio legis atual, para que satisfaça às novas necessidades sem, contudo, mudar-se a lei (FERRARA, 2005). Certamente, o ponto mais sensível a ser considerado nesse debate passa pelo reconhecimento de que a entrada forçada, sem que se tenha prévia justificação respaldada pelo Direito, é arbitrária. Isso implica, portanto, o reconhecimento de que eventual constatação de flagrante delito em momento posterior à invasão do domicílio não justificaria a tomada dessa decisão, consistente diretamente na violação de norma que garante a proteção, não apenas formal, mas, principalmente, material do domicílio privado. Nesse sentido, a constatação meramente casual, intuitiva ou de opinião, quanto à ocorrência de flagrante delito a posteriori, não torna lícita nem legítima a violação do domicílio. Dito de outro modo, a "proteção contra a busca arbitrária exige que a diligência seja avaliada com base no que se sabia antes de sua realização, não depois.” (BRASIL, 2015b, p. 19). Ou seja:

[...] sem desconsiderar a natureza permanente do delito de tráfico de drogas (para ilustrar), as circunstâncias da abordagem do caso concreto devem evidenciar ex ante situação de flagrância a autorizar o ingresso na residência do réu, durante o dia e, mais ainda, à noite, sem permissão e sem mandado de busca e apreensão (SARLET; WEINGARTNER NETO, 2013, p. 562).

Situação análoga também foi, enfática e circunstanciadamente, enfrentada pelo Superior Tribunal de Justiça (STJ):

Embora a jurisprudência tenha caminhado no sentido de que as autoridades 
podem ingressar em domicílio, sem o consentimento do morador, em hipóteses de flagrante-delito de crime permanente - de que é exemplo o tráfico de drogas -, o entendimento merece ser aperfeiçoado, dentro, obviamente, dos limites definidos pela Carta Magna e pelo Supremo Tribunal Federal, para que se possa perquirir em qual medida a entrada forçada em domicílio é tolerável (BRASIL, 2017b, p. 11-12).

Desse modo, em razão do status constitucional de direito fundamental atribuído ao domicílio privado, com uma série de outros direitos a ele equiparáveis, o Estado de Direito passou a definir critérios, segundos os quais a intangibilidade desses direitos pode, regradamente, ser violada no interesse não de qualquer outro direito, mas apenas de direitos que exijam igual e inadiável proteção. Por assim dizer, se exige o controle judicial permanente das ações policiais, especialmente para que o deslinde das investigações criminais não fique ao livre-arbítrio de servidores que, a pretexto de atuarem segundo os interesses da segurança pública, ajam aniquilando em absoluto os direitos e as liberdades individuais. Nessa medida, o controle judicial, anterior ou posterior, conforme o caso, é indispensável e não deve se limitar a simplesmente chancelar investigações desenvolvidas de forma arbitrária e, em muitas situações, tão criminosamente quanto as supostas condutas particulares a que se destinavam combater (BRASIL, 2015b). Atente-se que, de acordo com considerável conjunto de decisões judiciais, lamentavelmente produzidas em desacordo com os padrões valorativos da Constituição e de Tratados de proteção dos direitos fundamentais, se houver ingresso da força policial no domicílio privado, sem prévia autorização judicial e, nesse caso, se confirmado o estado de flagrante delito, não se exigirá o controle judicial a posteriori, ficando, portanto, essa medida dispensada, o que implicará não se exigir explicações das autoridades policiais envolvidas, o que evidentemente constitui grave erro. Em situações como esta, de acordo com o novo entendimento firmado no RE, impõe-se fortalecer o controle judicial a posteriori, fazendo com que os agentes públicos envolvidos na diligência demonstrem que suas ações tiveram respaldo em elementos concretos e não apenas intuitivos, ou seja, é preciso demonstrar que dispunham de elementos tangiveis que justificariam o ingresso forçado no imóvel (BRASIL, 2015b).

Justifica-se esse entendimento, na medida em que as chamadas provas ilícitas são proscritas no vigente ordenamento jurídico e, ao lado delas, há um conjunto de outros elementos que não têm força probatória e não servem para justificar qualquer ação policial tomada arbitrariamente, como o são as informações de inteligência policial, as denúncias anônimas, informantes policiais etc. (BRASIL, 2015b). Devido a isso, a prova ilícita, devidamente configurada como tal, é reveladora da tensão presente na tutela de bens essenciais eleitos pela sociedade, que adota o processo penal como meio para a realização do direito punitivo, da liberdade e dos direitos dos cidadãos, a quem se imputa o cometimento de lesões aos bens ditos essenciais (DEU, 2014). Diante desse quadro, que envolve fatos e o próprio regime do Estado de Direito, além de toda a ordem principiológica na qual se assenta a Constituição Federal, a "locução fundadas razões demandará esforço de concretização e interpretação" (BRASIL, 2015b, p. 24), podendo-se estender essa conclusão também em relação aos "fun- 
dados indícios”. Some-se a isso que, no curso da apreciação do RE, duas ponderações foram externadas e têm forte carga persuasiva, na medida em que enfatizam a realidade tal como ela efetivamente se concretiza, quase sempre em detrimento dos direitos fundamentais das pessoas socialmente desfavorecidas. A primeira delas destacou a preocupação, justa e atual, de que, em regra, a força policial age de forma arbitrária, pois invade e arrebenta, sobretudo, as residências mais humildes e "depois dá uma justificativa qualquer", de forma oral na delegacia (BRASIL, 2015b, p. 29). A segunda destacou a falta de razoabilidade que envolve o controle da atividade policial, pois, evidentemente, quando há controle judicial prévio, o juiz apenas autoriza a realização de buscas domiciliares durante o dia e somente o faz se munido de elementos concretos, documentalmente consubstanciados, que o convençam da necessidade de se autorizar tal medida, ao passo que, se a decisão couber ao agente público, este poderá arrombar a casa, ingressar no seu interior, fazer buscas, apreensões e prisões, tudo baseado apenas em sua capacidade intuitiva, à revelia de qualquer ordem ou do regime constitucional, legal ou derivado dos Tratados internacionais (BRASIL, 2015b).

\section{DIREITOS FUNDAMENTAIS: ENTRE A ESSENCIALIDADE E O PRAG- MATISMO}

Como se percebe, "fundadas razões" e "fundados indícios" são conceitos vagos, abstratos, que têm aplicação sobre a mesma estrutura normativa e consubstanciam o núcleo de um sistema permissivo, segundo o qual agentes públicos podem ingressar no domicílio alheio. Nesse ponto, não se pode ignorar que princípios como os que resguardam a dignidade humana, a inviolabilidade da casa e a segurança da coletividade, que se condensa sob o regime da manutenção da ordem pública, podem entrar em conflito, sendo importante considerar que há princípios que enunciam uma razão para decidir em determinado sentido, mas também é possível que possam concorrer com outros princípios que deem razões para se decidir de forma contrária (CALSAMIGLIA BLANCAFORT, 1982). Precisamente em razão disso, impõe-se avaliar a tese de repercussão geral construída no RE n. 603.606-RO, a qual passou a admitir a entrada forçada de agentes públicos no domicílio privado, mesmo à noite, sem mandado judicial, desde que a decisão esteja amparada em "fundadas razões", as quais deverão ser justificadas a posteriori e indiquem que, dentro da casa, esteja ocorrendo situação de flagrante delito, sujeitando-se o infrator à responsabilização disciplinar, civil e penal, além da nulidade dos atos praticados, de modo a se determinar o que pode ser admitido como "fundadas razões" e se há limites que as restrinjam.

Tem-se, em primeiro lugar, que "fundadas razões" ou "fundados indícios" não podem receber interpretação tão aberta e pontual, ainda mais se essa tarefa competir ao próprio agente público que decidirá e concretizará a violação do domicílio privado. Nesse passo, a própria limitação da abertura interpretativa já se evidencia como balizamento extremo. Em 
segundo, convém lembrar que o princípio da lealdade na obtenção da prova constitui aporte de inquestionável interesse, pois se trata de princípio geral e de origem jurisprudencial, em virtude do qual se incorpora um conceito jurídico indeterminado, permitindo-se "excluir do processo aquelas provas obtidas com a utilização de mecanismos desleais, armadilhas ou estratagemas." (DEU, 2014, p. 61).

Tem-se o direito à proteção do domicílio como categoria própria de direito fundamental incorporado pela CF em um núcleo muito específico de normas diretamente vinculadas ao indivíduo. Mesmo considerando que os direitos fundamentais possam ser analisados na perspectiva abstrata ou concreta, não se pode ignorar que a relação desses direitos se conecta com outros que asseguram a liberdade individual, nas várias possibilidades em que se possa manifestar. Desse modo, seja pela substância, seja pela estrutura, os direitos fundamentais estão categorizados como emanações de uma concepção de Estado que, no caso brasileiro, é o Estado de Direito (ALEXY, 2006). Nessa ordem, normas que garantem direitos individuais gozam da qualificação de direitos fundamentais (ALEXY, 2006), e, certamente, a manutenção constante e indeclinável do Estado como Estado de Direito, em oposição à figura do Estado de Exceção, é importante limite a ser considerado no amplo espectro de proteção dos direitos fundamentais. Atente-se que o Estado de Direito, como idealização cultural, passou a ser invocado devido à circunstância de se poder distinguir, com clareza e determinação, entre aquilo que o "legislador impôs como norma e aquilo que um intérprete apresenta como razões para uma determinada interpretação” (ALEXY, 2006, p. 82), o que pode ser associado ao objeto desta pesquisa e resumido nas seguintes fórmulas propositivas: i) o Estado brasileiro é Estado de Direito; ii) o Estado de Direito resguarda o domicílio privado como bem jurídico inviolável; iii) a inviolabilidade do domicílio privado é relativa; iv) em razão dessa relatividade, admite-se o ingresso de agentes públicos no domicílio privado, inclusive à noite, mesmo sem autorização judicial, se nele estiver ocorrendo flagrante delito; v) considera-se crime de abuso de autoridade a invasão do domicílio sem a observância das formalidades legalmente exigidas; vi) "fundadas razões" ou "fundados indícios" devem ser elementos de convicção concretos e demonstráveis quanto à ocorrência de flagrante delito no interior do domicílio; vii) não se consideram "fundadas razões" ou "fundados indícios" meras opiniões, "achismos" ou intuições, como justificativas para a tomada da decisão que conduzirá à violação do domicílio, quando não se tenha previamente a autorização judicial; viii) "fundadas razões" ou "fundados indícios" são perspectivas subjetivas do agente público, mas devem constituir elementos concretos, demonstráveis e de conhecimento prévio, isto é, em momento anterior ao ingresso no domicílio privado, não se admitindo que esse conhecimento seja posterior à invasão.

Nessa medida, em conformidade com a teoria constitucional, os direitos fundamentais correspondem, essencialmente, aos direitos conferidos ao homem livre, estando associados a uma concepção de direitos absolutos em princípio, mas que podem ser relativizados segundo critérios legais, de onde se extrai que somente a lei poderá limitá-los. Com efeito, é nesse 
contexto que a proteção do domicílio foi inserida na Constituição, recebendo consequentemente a classificação de direito fundamental de primeira geração ou de liberdade, em uma clara conformação de direito de resistência ou de oposição do indivíduo em face do Estado (BONAVIDES, 2014). Dessa forma, somente à lei caberia definir os termos precisos sobre eventual limitação do direito fundamental à inviolabilidade do domicílio, respeitando-se os limites já definidos pela Constituição, e, dentro dessa moldura, garantir que a proteção constitucional ao bem jurídico prevaleça sobre as possibilidades de relativização definidas em lei, que sejam abusivas e extrapolem o núcleo essencial que define a existência do próprio direito.

Não há como negar que os direitos e as garantias individuais catalogados no art. 50 da CF se qualificam como preceitos fundamentais (MENDES, 2007). Sob esse olhar, já se havia definido o crime de abuso de autoridade, praticado mediante violação do domicílio (Lei n. 4.898/1965), ao qual o ordenamento jurídico atribuiu a qualidade de infração de menor potencial ofensivo (Lei n. 9.099/1995). Todavia, mais recentemente, o Parlamento brasileiro apresentou nova proposta de definição desse crime (PLS n. 85/2017), ao qual corresponderá a qualificação de infração de médio potencial ofensivo. Assim, de acordo com a técnica legislativa, tanto a lei hoje existente quanto a nova proposta de (re)definição desse fato-tipo, conduz à simples e indiscutível conclusão de que a violação do correspondente bem jurídico por agentes públicos os sujeitarão, tão somente, a medidas despenalizadoras, isto é, à transação penal, quanto ao crime de que cuida a Lei n. 4.898/1965, ou à suspensão condicional do processo quanto ao novo crime de que trata o PLS n. 85/2017, acaso venha a ser convertido em lei.

Ademais, na visão do legislador ordinário, havendo "fundadas razões" ou "fundados indícios”, poder-se-á proceder à busca domiciliar, prender pessoas, apreender objetos, instrumentos etc., mesmo não se tendo, com clareza e exatidão, o sentido e o alcance que se possa atribuir a tais expressões. Note-se que a segurança jurídica, que implica exigência de lei certa, entrou em crise com o moderno Direito Penal, isso porque a tendência do legislador na atualidade é de se expressar de forma pouco clara, verificando-se cada vez mais ambiguidades e imprecisões nos textos legislativos da seara penal (BUSATO; HUAPAYA, 2003).

Nessa mesma linha, Hassemer destacou a tendência de o legislador moderno expressar-se de forma obscura, carregando o peso da decisão que deveria ser sua, cada vez mais, para os ombros alheios (HASSEMER, 2003, p. 18). Mas, além disso, não parece que o legislador tenha conferido ao domicílio privado o valor equivalente àquele conferido a esse bem jurídico segundo o projeto constituinte originário, que lhe assegurou status de direito fundamental, podendo-se identificar na atualidade sua proteção insuficiente. Portanto, em termos práticos, caberá ao agente público a decisão sobre ingressar no domicílio privado diante das circunstâncias ocasionais, traduzindo-as como suporte fático "legitimador", que o autorizará concluir pela ocorrência, ou não, de situação típica de flagrante delito, postergando-se para outro momento a discussão acerca da legalidade de sua decisão. Em outras palavras, o agente público interpretará os fatos e decidirá de ofício, por ato exclusivo, o que não representa medida de acerto ou desacerto, mas de evidente discricionariedade em face de ato relevante e, ao mesmo 
tempo, comprometedor, como o é a violação do domicílio à revelia de exaustivo, percuciente, prévio e isento controle judicial.

À luz dessa realidade, argumentou-se não ser possível "que haja uma invasão de domicílio e depois não se encontre nada, e a Polícia simplesmente peça desculpas depois de arrombar a porta do barraco ou da casa de luxo, ou o ingresso num condomínio fechado" (BRASIL, 2015b, p. 45), de modo que, nessa ordem, torna-se absolutamente necessária a adoção de todos os cuidados em face da discricionariedade policial. Nesse contexto:

[...] é de particular importância (re)pensar em que medida o ingresso na esfera domiciliar para apreensão de drogas em determinadas circunstâncias representa uma intervenção restritiva legítima do ponto de vista constitucional e não uma violação do direito fundamental à inviolabilidade de domicílio. Isso porque a ausência de justificativas e de elementos seguros a autorizar a ação dos agentes públicos, diante da discricionariedade policial na identificação de situações suspeitas relativamente à ocorrência de tráfico de drogas, pode acabar esvaziando o próprio direito à privacidade e à inviolabilidade de sua condição fundamental (BRASIL, 2017b, p. 16).

Insistindo-se na irrepreensível advertência lançada no RE, de que, em regra, a força policial age de forma arbitrária, pois invade e arrebenta, sobretudo, as residências mais humildes e depois dá uma justificativa qualquer, de forma oral na delegacia, revelando-se tal comportamento como padrão da violência policial que se pratica no Brasil, impõe-se acrescentar e destacar, não com a pretensão de estigmatização, repulsa injustificada ou por mera demonização da classe policial, mas efetivamente por compromisso didático e propedêutico que, na maioria dos casos de práticas de abusos policiais, atos como a invasão de domicílio são realizados sem a presença de testemunhas imparciais e isentas. Isso ocorre porque, em regra, empregam-se policiais de uma mesma equipe ou de outra, para atuarem como testemunhas dos atos por eles mesmos praticados, do que resulta claro que um policial não testemunhará contra o outro, na medida em que, se assim o fizer, estará depondo contra si, seja porque foi cúmplice do ato abusivo ou violento praticado, seja porque, no mínimo, foi conivente e não impediu a ação criminosa, não amparada pelo Direito, levada a efeito por colega de profissão.

Para citar referência concreta dessa realidade, a Police Foundation (Washington, DC), organização privada, sem fins lucrativos, desenvolveu pesquisas acerca do abuso de autoridade pela polícia, que consubstanciaram a publicação intitulada: The Abuse of Police Authority, na qual se apurou que é comum que policiais fiquem cegos (blind eye) diante da conduta imprópria de outros policiais, de modo que, mesmo quando se trata de delatar graves violações criminais, 6 em 10 policiais deixam de relatar os graves casos de abusos de autoridade perpetrados por outros colegas policiais (WEISBURD, 2001). Nesse contexto, Kyra Moon realizou estudos sobre a incidência da violência policial no Brasil, tendo apurado que os índices são elevados, o que, para ela, é contraditório pelo fato de o País ser um “Estado Democrático”, visto como progressista em Direitos Humanos. Para a pesquisadora, há enorme diferença entre o que as leis de Direitos Humanos representam e a sua implementação. Assim, a título de esclarecimento, Kyra Moon identificou que a violência policial no Brasil reforça a alta prevalência da desigualdade, tanto 
que é sistematicamente exercida contra jovens pobres, negros ou mestiços, favelados, e, em boa medida, a polícia tem esses indivíduos como alvo de suas truculências, uma vez que integram o grupo de pessoas marginalizadas e se encaixam no estereótipo criminoso. Ademais, essas vítimas têm medo dos policiais e, consequentemente, não os denunciam (MOON, 2009). Nessa ordem, confirmando o raciocínio desenvolvido no RE, de que, em regra, são as comunidades em situação de vulnerabilidade social as que estão mais suscetíveis de serem vítimas das formas de ingerências arbitrárias em seus domicílios, não há espaço para ingenuidades ou hipocrisias em face de casos típicos de invasão policial nos domicílios privados, pois, quando se verifica que não há, verdadeiramente, situação de flagrante delito, apela-se, em regra, para o subterfúgio de "plantar provas incriminadoras", por exemplo, a falsa "localização" de armas, munições, drogas, instrumentos de crimes e outros objetos que, em razão de suas naturezas, sua posse/detenção configure crime e, consequentemente, imponha a prisão de pessoas e a apreensão de tais produtos, assim como a responsabilização criminal em decorrência da malícia e do despreparo moral de servidores policiais, que convertem o poder inerente às suas funções em instrumento de intimidação, de vingança pessoal ou institucional e de favorecimento à corrupção. Essa visão, por certo, consubstanciou o exame do RHC n. 117.159-RJ:

Por que a polícia não buscou um mandado de prisão judicial para invadir a residência do paciente? Não sei. Não sei porque desconheceu a ordem jurídica. Não houve qualquer sinalização de prática criminosa no local, quando se poderia cogitar do flagrante. O que houve foi uma invasão domiciliar, sem ordem judicial, e descobriu-se que, no local, se teria uma arma guardada e, também, tóxico. Entendo que a prova se mostrou ilícita, ante a violência perpetrada pelo aparelho policial (BRASIL, 2013, p. 16).

O Brasil, lamentavelmente, não é referencial positivo quando comparado a outros países no tocante à atuação profissional, ética e controlada, com seriedade e imparcialidade, quanto às ações de policiais corrompidos inseridos nas corporações e nas estruturas administrativas dos órgãos de segurança pública. Para se ter dado comparativo, concreto e conhecido, vale destacar a atuação da Suprema Corte dos Estados Unidos em relação ao direito contra a autoincriminação disposto na $5^{\text {a }}$ Emenda, acolhido como técnica empregada para atenuar a vulnerabilidade do preso. Com esse entendimento e com o que mais esteve definido quanto ao julgamento do caso (no qual foram discutidos os direitos do réu Ernesto Miranda, que teriam sido violados por ação da polícia), consequências reais tiveram imediata incidência no modo de abordagem e na execução de prisões pela polícia, em decorrência de atividade investigativa ou de manutenção da ordem pública.

Esse caso, que ficou conhecido como Miranda's Rights (processo oficialmente registrado na Suprema Corte dos Estados Unidos como Miranda v. Arizona, 384 U.S. 436 1966), teve como principal consequência a definição de que qualquer pessoa, após ser presa e antes de ser interrogada sobre o crime que lhe fosse atribuído, deveria ser advertida: i) do direito de permanecer em silêncio; ii) de que qualquer declaração sua poderia e seria usada contra ela no tribunal; iii) do direito de consultar advogado e de ter a presença de um enquanto esti- 
vesse sendo interrogada; iv) de que, se não pudesse pagar advogado, um the seria nomeado para representá-la e v) de que poderia decidir a qualquer momento exercer esses direitos e não responder a quaisquer perguntas ou fazer quaisquer declarações. Por último, feitas essas advertências, a pessoa presa ainda deveria ser inquirida se entendeu os direitos que lhe foram explicados e, se afirmativo, se desejaria falar, renunciando a eles. Obviamente, a atividade interpretativa da Suprema Corte no caso Miranda v. Arizona se revelou importante instrumento para a defesa dos direitos individuais, uma vez que, ao se impor contra o Estado em relação ao exercício da persecução penal ou por ocasião de simples abordagens policiais, como atividade própria de manutenção da ordem pública, gerou um mínimo de equilíbrio de forças entre o Estado e o indivíduo (THE SUPREME COURT, 2006).

Entretanto, o ponto fulcral desse caso concreto pode ser resumido na mudança da atuação das corporações policiais, uma vez que quaisquer declarações feitas pelo preso, sem atendimento aos citados direitos, não poderiam ser admitidas como provas na eventualidade de se ajuizar a ação penal. A consequência imediata dessa decisão pode ser definida com a mudança da prática policial, a qual passou a incorporar em sua rotina, como procedimento regular, esclarecimentos às pessoas abordadas quanto aos direitos que passaram a ser conhecidos como Miranda's Rights, tanto que, uma vez satisfeitas essas condições, dizia-se que a pessoa presa foi Mirandized, o que significa o ato de dar ciência à pessoa presa quanto aos seus direitos, de acordo com a decisão proferida pela Suprema Corte dos Estados Unidos no caso Miranda v. Arizona.

Finda-se por dizer que os valores constitucionais estabelecidos não podem sucumbir frente ao simples pragmatismo policial, de modo que fórmulas abertas e expostas a qualquer rumo interpretativo não podem deixar o domicílio privado com as portas escancaradas para o ingresso de forças policiais, atribuindo-se a estas a oportunidade e a ampla discricionariedade sobre o que para elas signifiquem as expressões "fundadas razões" e "fundados indícios".

\section{INTERPRETAÇÃO E RETÓRICA NO JULGAMENTO DO RECURSO EXTRAORDINÁRIO N. 603.616-RO}

Toda liberdade sem limites tem consequências, geralmente, desagradáveis. Assim, a abertura interpretativa conferida pelo STF no julgamento do RE n. 603.616-RO, especialmente pela ausência de definição do sentido e alcance da expressão "fundadas razões", aplicando-se o mesmo entendimento para a expressão "fundados indícios", constitui, antes de qualquer outro sentido, que a elas se possa emprestar retrocesso interpretativo, isso porque, preambularmente, se "toda linguagem contém em si um modo ou uma repetição prévia do que é dito" (SCHLEIERMACHER, 2015, p. 12), pode-se igualmente afirmar que a linguagem também favorece aquilo que não foi dito, mas que se pode situar nas entrelinhas. Desse modo, a expressão "fundadas razões" poderá ser interpretada de modo a reforçar a proteção ao domicílio, ajustando-se ao projeto constitucional originário (concepção Garantista), assim 
como aproximando-se dele, mas também poderá ser interpretada de forma menos garantista e mais pragmática, favorecendo a atuação policial, mesmo quando esta visar à obtenção de provas com o emprego de mecanismos desleais, armadilhas ou estratagemas (concepção de Lei \& Ordem). Mas, o que isso representa? Exemplificativamente, considere a posição de um policial a quem se atribuiu uma investigação criminal, sendo ele comprometido com suas responsabilidades e, em especial, com o fiel cumprimento das leis. Em tais condições, por prudência, ele certamente indagaria, a quem pudesse auxiliá-lo, o que deveria entender por "fundadas razões", na hipótese de surgir situação que implicasse seu ingresso no domicílio da pessoa investigada e não dispusesse de autorização judicial.

A respeito disso, convém ter como referência que a atividade persecutória é condicionada pela necessidade de produção de provas, cuja busca pela chamada "verdade material" constitui uma das mais evidentes finalidades do processo penal, na medida em que se pauta pela oficialidade na fase investigativa e no correspondente processo penal, em especial em temas relacionados com a investigação e a obtenção de provas e respectivos meios probatórios (DEU, 2014, p. 26). De fato, tal pergunta é relevante e pertinente, na medida em que nem a legislação nem os argumentos expendidos no RE n. 603.606-RO a responderam. Nessa situação, não se tem a fixação de limites para a atuação policial em face dessa expressão, podendo-se falar de fracas evidências ou conjecturas, apenas, mas nada o suficiente que possa autorizar a tomada de decisão consciente e amparada pelo Direito quanto à inviolabilidade do domicílio, na hipótese de não se dispor de autorização judicial. Tratando-se de valores constitucionais, sabe-se que estes são compatíveis com o Estado de Direito, ao passo que meras evidências não o são (MARTINS, 2013a). Nesse aspecto, caberia ao sistema jurídico o ônus de operar a devida aproximação com o sistema social de modo a escutá-lo, empregar os instrumentos necessários e perceber o que politicamente está em jogo (MARTINS, 2013b). Em outras palavras, caberia ao sistema jurídico o ônus de interpretar a norma, visando a conhecê-la em sentido e alcance, além de explicar o significado de seus vocábulos, com o verdadeiro sentido da expressão (MAXIMILIANO, 2011), o que representa fase precedente quanto à aplicação do correspondente Direito, isto é, a transformação da lei abstrata e sua efetiva aplicação ao caso concreto, algo que se relaciona com a regular operabilidade do sistema jurídico. Desse modo, no questionamento feito pelo policial, estaria contida essa preocupação.

Assim sendo, diante do desconhecimento e da justificável preocupação revelados segundo a óptica de um servidor policial cauteloso, confirma-se que a clareza do texto ou de seu sentido não pode estar assegurada em absoluto, embora o possa ser apenas convencionalmente, de maneira a se limitar voluntariamente o contexto no qual "convenha" interpretá-lo (PERELMAN, 2014, p. 142-143). Ademais, a clareza do texto está condicionada, inquestionavelmente, pelas possibilidades de sua interpretação (PERELMAN, 2014). Nesse plano, não se pode ter a ilusão ou a falsa crença de que tudo é conciliável, primeiro porque a infinita complexidade das interpretações explica a impossibilidade de redução de todos os possíveis enunciados, a 
exemplo de "fundadas razões" e de "fundados indícios", proposições cuja probabilidade numérica possa ser determinada (PERELMAN, 2014, p. 138). Em segundo, porque a indefinição da jurisprudência, que segue rumos diferentes de acordo com a qualidade pessoal das partes envolvidas (rememore-se que, em regra, são as comunidades em situação de vulnerabilidade social as que estão mais suscetíveis de serem vítimas de formas de ingerências arbitrárias em seus domicílios), promove a maior das inseguranças jurídicas, na medida em que pode desqualificar e intimidar a atuação de profissionais sérios e comprometidos, mas, ao mesmo tempo, pode igualmente estimular a atuação impune daqueles outros vocacionados e viciados com as facilidades práticas de produção de provas ilícitas, mediante o emprego de meios proscritos e moralmente rejeitados pelo ordenamento jurídico, pois, conforme mencionado, muitas vezes, a força policial age de forma arbitrária, pois invade e arrebenta, sobretudo, as residências mais humildes e depois dá uma justificativa qualquer, de forma oral, na delegacia.

É fácil concluir que, se o policial prudente e cauteloso buscasse amparar-se na orientação contida no RE examinado, nele, não encontraria a resposta à sua indagação sobre o que deveria entender por "fundadas razões”. Assim, devido à falta de sistematização, que se pode atribuir tanto à legislação quanto à jurisprudência, criaram-se espaços de acomodações de discussões em que facilmente se inserem teorizações que buscam solucionar problemas dessa ordem. Duas delas são usualmente invocadas, mas, embora meritórias, são incompatíveis. A primeira delas, a concepção Garantista, firmou-se no pressuposto básico de que, para se intentar a construção de um processo penal funcional e garantidor, há de se perseguir a meta de conciliar as necessidades de garantia do cidadão com a não menos necessária funcionalidade e eficiência do sistema punitivo (FERNANDES, 2000). A segunda se refere à concepção de Lei \& Ordem decorrente do programa "Tolerância Zero", desenvolvido pela Polícia de Nova York, que adquiriu certa popularidade no cenário internacional, inclusive no Brasil. Essa concepção tem servido de plataforma para discursos políticos e de objeto de estudos relacionados com a segurança pública. Assim, "Tolerância Zero” representa, por um lado, a confirmação de que o Estado pode impor a lei e a ordem, pautando-se em uma manifestação de repúdio firme e intransigente contra a criminalidade. Por outro lado, pode significar o fortalecimento das instituições policiais, mediante o aporte de recursos que favorecerão o combate à criminalidade, como a aquisição de novos equipamentos, a contratação de mais pessoal e até o aprimoramento de ações de planejamento estratégico e operacional. Ocorre, não obstante, que as opções de atuação do Estado marcam o tensionamento contínuo entre as concepções Garantista e de Lei $\&$ Ordem, especialmente porque a realidade demonstra a todo tempo que o problema da violência generalizada, visível ante os altos índices de criminalidade, principalmente da urbana, reduz-se a uma questão de polícia, embora, paradoxalmente, tudo isso esteja inserido no regime do Estado de Direito. Afirma-se, diante desse cenário, que "Tolerância Zero" atua "como arma adicional na defesa de políticas de segurança pública”, algo que pode estar associado à configuração de relações sociais excludentes e autoritárias, que estão enraizadas na sociedade brasileira (BELLI, 2000, p. 170). Nesse contexto, não custa lembrar, com amparo 
em Eric Hobsbawm, que o mundo atual se encontra repleto de aparelhos policiais e serviços de segurança pública que atuam convencidos de que não é o "Estado de Direito", mas sim a "Força" e a "Violência", se necessária, que asseguram a manutenção da ordem pública, independentemente do que digam os governos (HOBSBAWN, 2007, p. 147-148).

Diante do exposto, principalmente em virtude da indefinição sobre o real sentido e alcance das expressões "fundadas razões" e "fundados indícios", ao adotar-se postura nitidamente garantista, de modo a conferir maior proteção ao domicílio privado, ter-se-á que, para "o reconhecimento do estrito cumprimento do dever legal, será preciso que tanto os meios utilizados quanto o fim perseguido estejam em consonância com o direito" e, devido a isso, “não se pode dizer que se trate de hipótese em que os fins 'santificam' os meios" (BRODT, 2011, p. 1). O oposto disso, ao se relegarem as garantias individuais ao plano secundário, preferindo-se a produção de resultados puramente práticos da ação policial, descontrolada e não orientada pelas regras do Direito, corre-se o risco de que produzir provas ilícitas e/ou ilegítimas seja mais vantajoso, mesmo que, com isso, o direito fundamental à proteção do domicílio seja sacrificado e perca toda a sua essencialidade e a razão de positivação. Desse modo, a abertura interpretativa que se pode estabelecer em razão do indeterminismo das expressões "fundadas razões" e "fundados indícios" atua em franca contradição com o discurso constitucionalista moderno, considerando a base da história dos direitos fundamentais que, na origem, foi a história por muitos séculos do absolutismo e mais recentemente dos regimes totalitários e autoritários de várias tendências (MIRANDA, 2018, p. 1-14).

\section{CONCLUSÃO}

A abordagem que coloca no centro da discussão a análise de conteúdo retórico de normas jurídicas criadas e moldadas com a pretensão de garantir a satisfação plena de direitos individuais fundamentais, valendo-se de mecanismos interpretativos, demonstra que se pode ofuscar e até tornar inefetivas estas mesmas garantias, por ser desarrazoado esperar e acreditar que, diante de expressões tão vagas, como "fundadas razões" e "fundados indícios", o Estado, representado na pessoa do servidor policial, possa transpor a regra que garante a inviolabilidade do domicílio privado e, ainda, respeitar os direitos fundamentais individuais.

O experimentalismo, o pragmatismo e a realidade concretamente conhecidos revelam que não há práticas de autocontenção, de consciência social ou de reconhecimento do Estado de Direito, quando as forças do Estado brasileiro se determinam em invadir o imóvel particular, visando à obtenção de provas e à prisão de pessoas, especialmente quando as partes sobre as quais incidirem a persecução pertencerem às classes sociais desfavorecidas, e suas residências se situarem em ambientes socioeconômicos precários.

É absolutamente incompatível com o Estado de Direito admitir que, ante a exceção do regime de controle judiciário prévio para a concessão de autorização para o ingresso no domicílio, em busca de provas e para a realização de prisões que visem a subsidiar o processo 
penal, atribua-se ao servidor policial, de forma pessoal, exclusiva e discricionária, a decisão sobre a invasão do domicílio privado, cumprindo a esse servidor a definição das "fundadas razões" ou dos "fundados indícios" que a legitimam.

A tese firmada no RE n. 603.616-RO, assim como as disposições previstas no art. 240, § 1॰, do CPP e no art. 22, § 2º, do PLS n. 85/2017, como genuínas manifestações da soberania estatal, se mantidas como estão, servirão apenas para sedimentar a perspectiva atual de que as instituições anunciam em seus discursos propostas e pretensões de convencimento pautadas nas garantias do Estado de Direito, mas, ao final, suas ações se concretizam em torno do Estado de Exceção, de modo que os chamados direitos fundamentais têm seu campo de efetividade muitíssimo limitado e condicionado.

\title{
THE LEGISLATIVE ACTIVITY AND THE GENERAL REPERCUSSION THESIS FOR THE PROTECTION OF PRIVATE DOMICILE
}

\begin{abstract}
The article develops a critical analysis about the systematization of the most appropriate interpretation on the crime of abuse of authority arising from the violation of domicile, resulting in arrests and/or seizure of property and objects allegedly related to the practice of criminal offenses. The approach is placed at the center of the discussion, the analysis of the rhetoric content in legal norms created with the aspiration of guaranteeing full satisfaction of individual fundamental rights in opposition to anti-crime policy, highlighting the conflict of adequacy and purpose between the Legislative Project n. 85/2017 (Senate), the Extraordinary Appeal n. 603.616-RO (Federal Supreme Court) and the Federal Constitution. The study is appropriate and relevant, given that it contextualizes the current scenario of uncertainties that involves the entire political and administrative machinery of the Brazilian State regarding legislative decision making in criminal policy, and the mismatch between the pretension of being the guarantor of fundamental rights, the control of police activity and the new definition of the crime of abuse of authority, posed as challenges of the criminal legislative policy.
\end{abstract}

Keywords: Fundamental Rights. Legal Interpretation. General Repercussion Thesis. Protection of Private Domicile.

\section{LA ACTIVIDAD LEGISLATIVA Y LA TESIS DE REPERCUSIÓN GENERAL PARA LA PROTECCIÓN DEL DOMICILIO PRIVADO}

\section{RESUMEN}

El presente artículo desarrolla un análisis crítico que envuelve la sistematización sobre la interpretación más adecuada del crimen de abuso de autoridad proveniente del allanamiento 
de morada, del que resulte en la prisión de personas y/o en la incautación de bienes y objetos relacionados, en tesis, con la práctica de las infracciones penales. El abordaje pone en centro de discusión el análisis del contenido retórico de las normas jurídicas creadas con la pretensión de garantizar la satisfacción plena de los derechos fundamentales individuales en confronto con la política de combate a la criminalidad, destacándose así el conflicto de adecuación y finalidad entre el Proyecto Legislativo (PLS) n. 85/2017 (Senado), el Recurso Extraordinario (RE) n. 603.616-RO, Supremo Tribunal Federal (STF) y la Constitución Federal (CF). El estudio resulta oportuno y relevante, teniendo en cuenta que se contextualiza en el actual escenario de indefiniciones que envuelve toda la máquina política y administrativa de la Nación Brasileña en relación a la toma de decisiones legislativas en el ámbito de la política criminal, que envuelve la divergencia entre la pretensión garantista de los derechos fundamentales, el control de la actividad policial y la nueva definición del crimen de abuso de autoridad, colocados como desafíos de la política legislativa penal.

Palabras clave: Derechos Fundamentales. Interpretación Jurídica. Tesis de Repercusión General. Protección del Domicilio Privado.

\section{REFERÊNCIAS}

ALEXY, Robert. Teoria dos direitos fundamentais. Tradução Virgílio Afonso da Silva. 5. ed. São Paulo: Malheiros, 2006.

ALVES JUNIOR, Luís Carlos Martins. Direitos constitucionais fundamentais. Belo Horizonte: Mandamentos, 2010.

AMBOS, Kai. O processo acusatório e a vedação probatória: perante as realidades alemã e brasileira. Porto Alegre: Livraria do Advogado, 2009.

BELLI, Benoni. Polícia, "Tolerância Zero" e exclusão social. Novos Estudos CEBRAP, n. 58, p. 157-171, nov. 2000. Disponível em: <http://novosestudos.org.br/v1/contents/ view/933>. Acesso em: 27 fev. 2018.

BONAVIDES, Paulo. Curso de direito constitucional. 29. ed. São Paulo: Malheiros, 2014.

BRASIL. Decreto-Lei no 3.689, de 3 de outubro de 1941. Código de Processo Penal. Presidência da República, Brasília, DF, 1941. Disponível em: <http://www.planalto.gov.br/ ccivil_03/decreto-lei/Del3689Compilado.htm>. Acesso em: 20 fev. 2018.

. Constituição da República Federativa do Brasil: texto constitucional promulgado em 5 de outubro de 1988, com as alterações determinadas pelas Emendas Constitucionais de Revisão nos 1 a 6/94, pelas Emendas Constitucionais nos 1/92 a 91/2016 e pelo Decreto Legislativo no 186/2008. Brasília: Senado Federal, 2016. 
. Lei no 4.898, de 9 de dezembro de 1965. Regula o Direito de Representação e o processo de Responsabilidade Administrativa Civil e Penal, nos casos de Abuso de Autoridade. Presidência da República, Brasília, DF, 1965. Disponível em: <http://www.planalto.gov.br/ccivil_03/leis/L4898.htm>. Acesso em: 19 fev. 2018.

Lei no 9.099, de 26 de setembro de 1995. Dispõe sobre os Juizados Especiais Cíveis e Criminais e dá outras providências. Presidência da República, Brasília, DF, 1995. Disponível em: <http://www.planalto.gov.br/ccivil_03/leis/L9099.htm>. Acesso em: 19 fev. 2018.

Senado Federal. Projeto de Lei no 85, de 2017. Define os crimes de Abuso de Autoridade e dá outras providências. Senado Federal, Brasília, DF, 2017a. Disponível em: <https://www25.senado.leg.br/web/atividade/materias/-/materia/128545>. Acesso em: 19 fev. 2018.

. Superior Tribunal de Justiça. Recurso Especial no 1.574.681 RS. Sexta Turma. Relator Min. Rogério Schietti Cruz. Julgado 20/04/2017, p. 1-27. 2017b. Disponível em: <https://ww2.stj.jus.br/websecstj/cgi/revista/REJ.cgi/ATC?seq $=68547748 \&$ tipo=91\& nreg $=201503076023 \&$ SeqCgrmaSessao $=\&$ CodOrgaoJgdr $=\& d t=20170530 \&$ formato=PDF\& sal var=false>. Acesso em: 28 fev. 2018.

Supremo Tribunal Federal. Repercussão Geral. Boletim, Brasília, v. 1, n. 6, p. 1-68, dez. 2015a. Disponível em: <http://www.stf.jus.br/portal/cms/verTexto.asp?servico= publicacaoInformativoRG\& pagina=BoletimdaRepercussaoGeral2015>. Acesso em: 23 fev. 2018.

. Supremo Tribunal Federal. Recurso Extraordinário n. 603.616 RO. Relator Min. Gilmar Mendes. Portal STF, Rondônia, p. 1-63, 5 nov. 2015b. Disponível em: <http:// www.stf.jus.br/portal/geral/verPdfPaginado.asp?id=10924027\& tipo=TP\&descricao=Intei ro\%20Teor\%20RE\%20/\%20603616>. Acesso em: 22 fev. 2018.

. Supremo Tribunal Federal. Recurso Ordinário em Habeas Corpus n. 117.159 RJ. Primeira Turma. Relator Min. Luiz Fux. Redir, p. 1-17, 5 nov. 2013. Disponível em: <http://redir.stf.jus.br/paginadorpub/paginador.jsp?docTP=TP\&docID=4953933>. Acesso em: 25 fev. 2018.

. Supremo Tribunal Federal. Recurso Ordinário em Habeas Corpus n. 123.949 SP. Primeira Turma. Relator Min. Marco Aurélio. Redir, p. 1-13, 6 out. 2015c. Disponível em: <http://www.stf.jus.br/portal/inteiroTeor/obterInteiroTeor.asp?idDocumento=9823110>. Acesso em: 26 fev. 2018.

. Supremo Tribunal Federal. Recurso Ordinário em Habeas Corpus n. 86.082-6 RS. Segunda Turma. Relatora Min. Ellen Gracie. DJe, n. 157, p. 240-250, 22 ago. 2008. Disponível em: <http://redir.stf.jus.br/paginadorpub/paginador.jsp?docTP=AC\&docID= 
542891>. Acesso em: 25 fev. 2018.

BRODT, Luís Augusto Sanzo. Parâmetros do estrito cumprimento do dever legal. 2011. p. 1-5. Disponível em: <http://egov.ufsc.br/portal/conteudo/par\%C3\%A2metros-do-estrito-cumprimento-do-dever-legal>. Acesso em: 27 fev. 2018.

BUSATO, César Paulo; HUAPAYA, Sandro Montes. Introdução ao direito penal: fundamentos para um sistema penal democrático. Rio de Janeiro: Lumen Juris, 2003.

CALSAMIGLIA BLANCAFORT, Albert. Sobre la Dogmática Jurídica presupuestos y funciones del saber jurídico. Anales de la Cátedra Francisco Suárez, n. 22, p. 235-276, 1982.

CERVINI, Raúl. Os processos de descriminalização. 2. ed. São Paulo: Revista dos Tribunais, 2002.

DEU, Teresa Armenta. A prova ilícita: um estudo comparado. Tradução José Giacomolli. São Paulo: Marcial Pons, 2014.

DIAS, Jorge de Figueiredo. Acordos sobre a sentença em processo penal: o "fim" do Estado de Direito ou um novo "princípio"? Coimbra: Conselho Distrital do Porto da Ordem dos Advogados Portugueses, 2011.

FERNANDES, Fernando Andrade. O processo penal como instrumento de política criminal. Coimbra: Livraria Almedina, 2000.

FERRARA, Francesco. Como aplicar e interpretar as leis. Tradução Joaquim Campos de Miranda. Belo Horizonte: Livraria Líder e Editora Ltda., 2005.

HASSEMER, Winfried. Crítica al derecho penal de hoy. 2. ed. Buenos Aires: Ad-Hoc, 2003.

HOBSBAWN, Eric. Globalização, democracia e terrorismo. Tradução José Viegas. São Paulo: Companhia das Letras, 2007.

MACHADO, Bruno Amaral; ALVES, Reinaldo Rossano. Comunidades epistêmicas e a produção dos decretos de indulto no Brasil. Revista Opinião Jurídica, Fortaleza, v. 15, n. 21, p. 50-76, jul./dez. 2017. Disponível em: <http://periodicos.unichristus.edu.br/index. php/opiniaojuridica/article/download/1465/585>. Acesso em: 13 abr. 2018.

MALATESTA, Nicola Framarino Dei. A lógica das provas em matéria criminal. Tradução Paolo Capitanio. 2. ed. Campinas: Bookseller, 2001.

MARTINS, Rui Cunha. O ponto cego do direito: the brazilian lessons. 3. ed. São Paulo: Atlas, 2013a.

A hora dos cadáveres adiados: corrupção, expectativa e processo penal. São Paulo: Atlas, 2013b. 
MAXIMILIANO, Carlos. Hermenêutica e aplicação do direito. 20. ed. Rio de Janeiro: Forense, 2011.

MENDES, Gilmar. Arguição de descumprimento de preceito fundamental: comentários à Lei n. 9.882. São Paulo: Saraiva, 2007.

MESSIAS, Irajá Pereira. Da prova penal. 2. ed. Campinas: Bookseller, 2001.

MIRABETE, Júlio Fabbrini. Juizados especiais criminais: comentários, jurisprudência, legislação. 3. ed. São Paulo: Atlas, 1998.

MIRANDA, Jorge. Direitos e deveres fundamentais do Homem. p. 1-24. Disponível em: <http://www.anima-opet.com.br/pdf/anima2/Jorge_Miranda.pdf>. Acesso em: 27 fev. 2018.

MOON, Kyra. Police Violence in Brazil. Revisiting Human Rights in Latin America. Human Rights \& Human Welfare, University of Denver, Denver, p. 116-131, 2009. Disponível em: <https://www.du.edu/korbel/hrhw/researchdigest/latinamerica2/digest-human\%20rights\%20in\%20latin\%20america\%20vol\%202.pdf>. Acesso em: 25 fev. 2018. MÜLLER, Friedrich. Unidade do ordenamento jurídico. Revista Opinião Jurídica, Fortaleza, v. 15, n. 20, p. 298-305, jan./jun. 2017. Disponível em: <http://periodicos.unichristus. edu.br/index.php/opiniaojuridica/article/download/1412/466>. Acesso em: 13 abr. 2018.

PERELMAN, Chaïm. Tratado da argumentação: a nova retórica. Tradução Maria Ermantina de Almeida Prado Galvão. 3. ed. São Paulo: Martins Fontes, 2014.

ROXIN, Claus. Política criminal e sistema jurídico-penal. Tradução Luís Greco. Rio de Janeiro: Renovar, 2002.

RUSCONI, Maximiliano A. ¿Un sistema de enjuiciamiento influido por la política criminal? In: BAIGÚN, David et al. (Coord.). Estudios sobre la justicia penal: homenaje al Profesor Julio B. J. Maier. Buenos Aires: Editores Del Puerto, 2005. p. 431-448.

SARLET, Ingo Wolfgang; WEINGARTNER NETO, Jayme. A inviolabilidade do domicílio e seus limites: o caso do flagrante delito. Revista de Direitos Fundamentais e Democracia, Curitiba, v. 14, n. 14.2, p. 544-562, jul./dez. 2013. Disponível em:<http:// revistaeletronicardfd.unibrasil.com.br/index.php/rdfd/article/download/470/358>. Acesso em: 25 fev. 2018.

SAVIGNY, Friedrich Karl Von. Metodologia jurídica. Tradução Hebe. A. M. Caletti Marenco. Campinas: Edicamp, 2001.

SCHLEIERMACHER, Friedrich D. E. Hermenêutica: arte e técnica da interpretação. Tradução Celso Reni Braida. 10. ed. Petrópolis: Vozes, 2015.

SUXBERGER, Antonio Henrique Graciano; CANÇADO, Mayara Lopes. Políticas públicas de proteção à vítima: uma proposta de arranjo institucional de segurança pública. 
Revista Opinião Jurídica, Fortaleza, v. 15, n. 20, p. 32-58, jan./jun. 2017. Disponível em: <http://periodicos.unichristus.edu.br/index.php/opiniaojuridica/article/download/1150/456>. Acesso em: 13 abr. 2018.

THE SUPREME COURT. Supreme court history: expanding civil rights. New York, NY, Thirteen/WNET, dec. 2006. Disponível em: <http://www.pbs.org/wnet/supremecourt/rights/landmark_miranda.html>. Acesso em: 23 fev. 2018.

VARELLA, Marcelo Dias; SANTOS, Rafael Seixas. Uma análise conceitual da dignidade como fundamento dos Direitos Humanos e sua invocação nas decisões do STF e da CIDH. Revista Opinião Jurídica, Fortaleza, v. 14, n. 19, p. 171-194, jul./dez. 2016. Disponível em: <http://periodicos.unichristus.edu.br/index.php/opiniaojuridica/article/download/996/391>. Acesso em: 13 abr. 2018.

WEISBURD, David et al. The abuse of police authority: a national study of police officer's attitudes. Washington, DC: Police Foundation, 2001. Disponível em: <https://www. policefoundation.org/wp-content/uploads/2015/06/Weisburd-et-al.-2001-The-Abuse-of-Police-Authority.pdf>. Acesso em: 25 fev. 2018.

ZANATTA, Airton. A transação penal e o poder discricionário do Ministério Público. Porto Alegre: Sérgio Antonio Fabris Editor, 2001. 